\title{
Pengaruh Tingkat Profitability, Solvability, Ukuran Perusahaan dan Ukuran Kantor Akuntan Publik Pada Penundaan Pemeriksaan \\ (Studi Empiris : Perusahaan Manufaktur Terdaftar di BEI Tahun 2013-2016)
}

\author{
Lia Dama Yanti ${ }^{1}$, Yunia Oktari ${ }^{2}$ \\ Universitas Buddhi Dharma \\ lia.d4may@gmail.com
}

\begin{abstract}
Abstrak
Penundaan pemeriksaan merupakan masalah penting berdampak pada ketepat waktuan penyampaian informasi akuntansi yang selanjutnya mempengaruhi hubungan pada keterkaitan informasi akuntansi. Tulisan ini sebelumnya yang telah dilakukan menemukan banyak faktor yang dapat mempengaruhi Penundaan pemeriksaan. Tujuan dari tulisan ini yaitu untuk mengetahui dan menganalisa faktor - faktor yang mempengaruhi Penundaan pemeriksaan. Faktor - faktor tersebut adalah profitability, solvability, ukuran perusahaan dan ukuran Kantor Akuntan Publik yang secara parsial dan simultan mempengaruhi Penundaan pemeriksaan pada perusahaan manufaktur yang terdaftar di BEI periode 2013 sampai dengan 2016 yang diambil dari http://www.idx.co.id. Data yang dipakai dalam tulisan ini adalah data sekunder berupa laporan pemeriksaan perusahaan dengan menggunakan purposive sampling sebagai metode pengambilan sampel dan didapatkan jumlah sampel sebanyak 55 perusahaan. Variabel independen dalam tulisan ini adalah ROA, SOLV, Log Total Aset dan Ukuran Kantor Akuntan Publik. Variabel dependennya adalah Penundaan pemeriksaan. Teknik analisis yang digunakan adalah analisa linear berganda. Hasil tulisan menunjukkan bahwa secara parsial profitabilitas, ukuran perusahaan dan ukuran Kantor Akuntan Publik tidak berpengaruh terhadap penundaan pemeriksaan. Sedangkan solvabilitas mempengaruhi penundaan pemeriksaan. Dari hasil pengujian secara simultan ditemukan bahwa kelima variabel independen mempengaruhi penundaan pemeriksaan.
\end{abstract}

Kata kunci: Profitability, Solvability, Ukuran Perusahaan, Kantor Akuntan Publik, Penundaan pemeriksaan

\section{Pendahuluan}

Pasar modal saat ini semakin banyak diperlukan oleh masyarakat sebagai sarana untuk menanam saham. Perkembangan pasar modal tersebut mendorong perusahaan-perusahaan go public yang terdaftar di pasar saham untuk lebih meningkatkan kualitas laporan keuangan perusahaannya. Perusahaan yang go public pertahun diwajibkan untuk menyampaikan laporan tahunannya kepada BEI dan para pemodal. Laporan keuangan merupakan dokumen penting bagi para pelaku dunia bisnis. Laporan keuangan memuat catatan-catatan tentang seluruh kegiatan bisnis yang dilakukan oleh sebuah bagian dalam suatu periode tertentu. Laporan keuangan juga mempunyai peranan penting sebagai dokumentasi dalam hal berkomunikasi antar para pelaku bisnis.

Keputusan penanam modal untuk berinvestasi pada perusahaan di pasar modal bukan hanya dilihat dari baik atau tidaknya kualitas laporan keuangan yang disajikan oleh perusahaan namun

\footnotetext{
${ }^{1}$ Korespondensi: Lia Dama Yanti. Universitas Buddhi Dharma. Jl. Imam Bonjol No. 41 Karawaci Ilir, Tangerang. lia.d4may@gmail.com

${ }^{2}$ Korespondensi: Yunia Oktari. Universitas Buddhi Dharma. Jl. Imam Bonjol No. 41 Karawaci Ilir, Tangerang. yunia.oktari@buddhidharma.ac.id
} 
ketepatan waktu dalam memgumumkannya laporan keuangan juga menjadi bahan pertimbangan penanam modal dalam berinvestasi (Handayani \& Wirakusuma, 2013)

Ketepatan waktu penyampaian laporan keuangan pemeriksaan perusahaan kepada pengguna laporan keuangan ini tergantung dari lamanya pemeriksaan untuk menyelesaikan pekerjaan pemeriksaannya. Semakin cepat selesai pekerjaan pemeriksaan, maka semakin cepat pula publikasi laporan keuangan. Keterlambatan penyampaian laporan keuangan akan menyebabkan reaksi negatif dari pelaku pasar modal karena laporan keuangan yang berisi laba seringkali dijadikan dasar oleh penanam modal dalam mengambil keputusan untuk kepemilikan saham (Efendi \& Utami, 2012).

Dalam menyajikan jasa pemeriksaan ini, pemeriksaan memberikan keyakinan yang positif atas asersi yang dibuat manajemen dalam riwayat laporan keuangan.

Salah satu kendala perusahaan dalam mempublikasikan laporan keuangan kepada masyarakat dan kepada Otoritas Jasa Keuangan (OJK) adalah ketepatan waktu pemeriksaan dalam menyelesaikan laporan pemeriksaannya. Pemeriksaan membutuhkan waktu yang relatif lebih lama untuk mencari hal-hal pembuktian atas laporan keuangan yang telah dikeluarkan oleh perusahaan sehingga terjadi peningkatan Penundaan pemeriksaan. (Kartika, 2009) berpendapat bahwa Penundaan pemeriksaan merupakan lamanya atau rentang waktu untuk penyelesaian pemeriksaan yang diukur dari tanggal penutupan tahun buku sampai dengan tanggal diterbitkannya laporan pemeriksaan. Umumnya, nilai informasi yang terkandung dalam laporan keuangan akan menurun searah dengan semakin lamanya waktu yang diperlukan pemeriksaan untuk memeriksa laporan keuangan.

Berdasarkan pengumuman yang dikeluarkan oleh BEI bahwa untuk tahun 2013, emiten yang terlambat melaporkan laporan keuangan pemeriksaanan untuk periode yang berakhir 31 Desember 2012 sebanyak 20 emiten dari total 470 emiten yang tercatat, hal ini berarti dari 4,3\% total emiten yang terdaftar di BEI. Sedangkan untuk tahun 2014, emiten yang terlambat melaporkan laporan keuangan pemeriksaanan untuk periode yang berakhir 31 Desember 2013 sebanyak 45 emiten dari total 548 emiten yang tercatat, hal ini berarti dari 8,2\% total emiten yang terdaftar di BEI (www.idx.co.id) dan dari 45 emiten tersebut 11 diantaranya adalah perusahaan manufaktur.

Tabel 1

Daftar Emiten yang terlambat menyampaikan Laporan Tahunan Tahun 2013

\begin{tabular}{|l|l|l|l|l|}
\hline No. & Kode & Nama & $\begin{array}{l}\text { Tanggal Laporan } \\
\text { Pemeriksaan }\end{array}$ & $\begin{array}{l}\text { Lama } \\
\text { Delay }\end{array}$ \\
\hline 1 & ISSP & $\begin{array}{l}\text { PT. Steel Pipe Industry of Indonesia } \\
\text { Tbk. }\end{array}$ & 2-Apr-14 & 92 hari \\
\hline 2 & KARW & PT. ICTSI Jasa Prima Tbk. & $25-$ Mar-14 & 84 hari \\
\hline 3 & MYOR & PT. Mayora Indah Tbk. & 30 -Apr-14 & $\begin{array}{l}120 \\
\text { hari }\end{array}$ \\
\hline 4 & ALTO & PT. Tri Banyan Tirta Tbk. & 11-Jun-14 & $\begin{array}{l}162 \\
\text { hari }\end{array}$ \\
\hline 5 & ARGO & PT. Argo Pantes Tbk. & 11-Apr-14 & 101 hri \\
\hline 6 & BRAM & PT. Indo Kordsa Tbk. & $25-$ Mar-14 & 84 hari \\
\hline 6 & CEKA & PT. Wilmar Cahaya Indonesia Tbk. & 7-Mar-14 & 66 hari \\
\hline 7 & DLTA & PT. Delta Djakarta Tbk. & 27-Mar-14 & 86 hari \\
\hline 8 & IKAI & $\begin{array}{l}\text { PT. Intikeramik Alamsri Indonesia } \\
\text { Tbk. }\end{array}$ & 27-Mar-14 & 86 hari \\
\hline 9 & KBLI & PT. KMI Wire \& Cable Tbk. & 20-Mar-14 & 79 hari \\
\hline 10 & SSTM & PT. Sunson Textile Manufacturer Tbk. & 25-Mar-14 & 84 hari \\
\hline 11 & STTP & PT. Siantar Top Tbk. & Data tidak ditemukan & \\
\hline
\end{tabular}


Ada beberapa emiten tidak menyampaikan laporan keuangannya karena perbedaan penggunaan tahun buku sehingga belum waktunya untuk menyerahkan laporan keuangannya. (beritasatu, 2014). Berdasarkan pengumuman yang dikeluarkan oleh BEI mengenai Penyampaian Laporan Tahunan ( Annual Report ) Tahun 2013, hingga tanggal 30 April 2014 perusahaan-perusahaan tersebut belum manyampaikan laporan tahunan tahun 2013 dan telah memberkan Peringatan Tertulis I.

Penundaan pemeriksaan merupakan salah satu topik yang banyak dibahas dalam tulisan akuntansi. Banyak tulisan yang telah dilakukan untuk mengetahui faktor-faktor yang dapat mempengaruhi Penundaan pemeriksaan. Tulisan mengenai Penundaan pemeriksaan telah banyak dilakukan, baik di dalam negeri maupun luar negeri seperti (Efendi \& Utami, 2012), (Kartika, 2009), (Ahmed \& Hossain , 2010), (Hersugondo \& Kartika, 2013).

Faktor-faktor yang menyebabkan Penundaan pemeriksaan sangat banyak. (Lianto \& Kusuma, 2010) menulis mengenai faktor-faktor profitabilitas, solvabilitas, ukuran perusahaan, umur perusahaan dan jenis industri. Hasil tulisan tersebut menemukan bahwa profitabilitas dan solvabilitas yang berpengaruh terhadap Penundaan pemeriksaan. (Indriyani \& Supriyati, 2012) yang menulis mengenai faktor-faktor yang mempengaruhi keterlambatan pemeriksaan laporan di Indonesia dan Malaysia, menemukan persamaan faktor yang mempengaruhi keterlambatan pemeriksaan laporan di Indonesia dan Malaysia yaitu ukuran perusahaan, profitabilitas, laba/rugi perusahaan dan rasio hutang terhadap ekuitas.

Penundaan publikasi laporan keuangan pemeriksaan merupakan selisih antara tanggal ditandatanganinya laporan pemeriksaan diterima sampai dengan tanggal publikasi laporan keuangan pemeriksaanan kepada Bapepam. Tulisan (Febrianty, 2011), leverage merupakan mengindikasikan kesehatan dari perusahaan. Rasio hutang terhadap aset yang tinggi memberikan tanda bahwa perusahaan sedang dalam kondisi kesulitan keuangan. Menurut (Carslaw \& Kaplan, 1991) rasio antara jumlah relatif hutang terhadap total aktiva mencerminkan kondisi keuangan dari perusahaan. Total hutang terhadap total rasio aset dapat mempengaruhi waktu penyelesaian pemeriksaan yang pada akhirnya akan berpengaruh terhadap jangka waktu perusahaan memgumumkannya laporan keuangan hasil pemeriksaanan, (Indriyani \& Supriyati, 2012).

(Ahmed \& Hossain, 2010), menulis tentang keterlambatan pemeriksaan laporan pada perusahaan publik di Bangladesh. Variabel yang digunakan adalah ukuran Kantor Akuntan Publik, pergantian pemeriksaan, jenis opini akuntan publik, jenis industri, profitability, pengaruh dan ukuran perusahaan. Hasil tulisannya menunjukkan bahwa semua variabel independen berpangaruh secara signifikan terhadap keterlambatan pemeriksaan laporan.

(Asthon, Willingham, \& Elliot, 1987), menulis hubungan antara penundaan pemeriksaan dengan beberapa variabel independen yang terdiri dari total pendapatan, status perusahaan publik atau non publik, kompleksitas perusahaan dan operasional, jenis industri, bulan penutupan tahun buku, kualitas sistem pengendalian internal, keuangan, pelaporan keuangan, EDP, campuran relatif antara waktu pemeriksaan pada interim dan akhir tahun, lamanya perusahaan menjadi klien kantor akuntan publik, besarnya laba atau rugi, tingkat profitability dan jenis opini.

(Carslaw \& Kaplan, 1991), melakukan tulisan mengenai Penundaan pemeriksaan pada perusahaan publik di New Zealand. Variabel yang digunakan adalah ukuran perusahaan, kepemilikan perusahaan, pemeriksaan, jenis opini akuntan publik, tahun buku perusahaan, dan proporsi hutang terhadap total asset. Variabel yang berpengaruh adalah perusahaan melaporkan kerugian dan ukuran perusahaan.

(Halim, 2000), melakukan tulisan tentang penundaan pemeriksaan di Indonesia dengan menggunakan sampel 287 perusahaan yang terdaftar di Bursa Efek Indonesia pada tahun 1997. (Subekti \& Widiyanti, 2004) berhasil membuktikan bahwa Penundaan pemeriksaan yang panjang dialami oleh perusahaan yang tingkat profitabilitasnya tinggi, ukuran perusahaan besar, 
perusahaan bukan keuangan mendapatkan opini non Wajar Tanpa Pengecualian dan dipemeriksaan oleh Kantor Akuntan Publik besar (the big six).

Tulisan yang dilakukan oleh (Efendi \& Utami, 2012) menunjukkan Penundaan pemeriksaan yang terjadi adalah antara 30 sampai dengan 136 hari dengan rata-rata sebesar 73,20 hari. (Angruningrum \& Wirakusuma, 2013) membuktikan Penundaan pemeriksaan yang terjadi adalah memiliki rata-rata sebesar 74,854 hari.

Meskipun telah banyak dilakukan tulisan tentang Penundaan pemeriksaan pada perusahaan yang terdaftar di BEI, namun masih banyak perbedaan hasil.

\section{Literature Review/Related Works}

\section{Penundaan pemeriksaan}

Lamanya waktu penyelesaian pemeriksaan terhitung mulai dari tanggal penutupan tahun buku sampai dengan tanggal diterbitkannya laporan pemeriksaan disebut keterlambatan pemeriksaan laporan atau Penundaan pemeriksaan. (Hugh \& Dyers, 1975), berpendapat bahwa:

"Audit report lag is the open interval of number of days from the year end to the date recorded as the opinion signature date in the pemeriksaan report".

Menurut (Asthon, Willingham, \& Elliot, 1987), (Carslaw \& Kaplan, 1991), "Audit Delay is the length of time from a company's fiscal year end to the date of the audit's report".

Menurut (Lawrence \& Glover, 1998), Penundaan pemeriksaan adalah lamanya hari yang dibutuhkan pemeriksaan untuk menyelesaikan pekerjaan pemeriksaannya yang diukur dari tanggal penutupan tahun buku hingga tanggal diterbitkannya laporan keuangan pemeriksaanan.

Penundaan pemeriksaan atau Keterlambatan pemeriksaan laporan dibagi menjadi 3 komponen, yaitu:

a. Sceduling Lag, yaitu selisih waktu antara akhir tahun fiskal perusahaan dengan dimulainya pekerjaan lapangan pemeriksaan.

b. Fieldwork Lag, yaitu selisih waktu antara dimulainya pekerjaan lapangan dan saat penyelesaiannya.

c. Reporting Lag, yaitu selisih waktu antara saat penyelesaian pekerjaan lapangan dengan tanggal laporan pemeriksaan.

\section{Profitability}

Menurut (Harahap, 2007) profitability adalah kemampuan perusahaan mendapatkan laba melalui semua kemampuan dan sumber daya yang ada seperti kegiatan penjualan, kas, modal, jumlah karyawan, jumlah cabang dan lain sebagainya. Profitability mempunyai pengaruh dalam penerbitan laporan keuangan. Perusahaan yang mempunyai profitability rendah atau dengan kata lain mengalami kerugian cenderung akan menunda penerbitan atas laporan keuangan karena kerugian merupakan kabar buruk yang akan berdampak negatif pada perusahaan seperti penurunan permintaan akan saham yang diterbitkan.

Mengukur efektivitas manajemen secara keseluruhan yang ditunjukkan oleh besar kecilnya tingkat keuntungan yang diperoleh dalam hubungannya dengan penjualan maupun investasi.

\section{Solvability}

Solvability seringkali disebut leverage ratio. Rasio leverage atau solvability menunjukkan kemampuan perusahaan untuk memenuhi segala kewajiban finansial perusahaan tersebut. Rasio leverage yang umum digunakan ada dua yaitu debt to total asset dan debt to total equity. 
Pengukuran rasio solvabilitas dapat dilakukan melalui dua pendekatan yaitu mengukur rasiorasio neraca dan sejauh mana pinjaman digunakan untuk pemodalan dan melalui pendekatan rasio laba rugi.

Tujuan perusahaan dengan menggunakan rasio solvability adalah:

a. Mengetahui keadaan keuangan perusahaan khususnya dalam hal kewajiban. Beberapa hal yang bisa kita ketahui adalah bagaimana posisi keuangan perusahaan terhadap kewajibannya apakah ada keseimbangan antara nilai aktiva dan modal.

b. Berdasarkan penilaian keseimbangan tersebut, kita dapat mengetahui apakah perusahaan tersebut dalam hal pendanaan dibiayai oleh hutang atau tidak.

c. Hasil dari penilaian pendanaan yang dilakukan oleh perusahaan, kita dapat melakukan penilaian apakah terdapat pengaruh secara langsung terhadap perusahaan tersebut.

\section{Metode Tulisan/Method}

Metode tulisan ini adalah tulisan kausal komparatif yang juga merupakan tulisan ex post facto, yaitu tipe tulisan yang dilakukan terhadap data yang dikumpulkan setelah terjadinya suatu fakta atau peristiwa. Tulisan ini menggunakan teknik dokumentasi dalam pengumpulan data sekunder berupa laporan keuangan didapatkan melalui mendownload data-data laporan keuangan di website resmi BEI (Bursa Efek Indonesia) dan Indonesian Capital Market Directory (ICMD). Data tulisan ini meliputi data perusahaan yang berupa laporan keuangan tahunan dan laporan pemeriksaanan per 31 Desember yang mencakup periode pelaporan pada tahun 2013-2016.

Tulisan ini menggunakan pendekatan kuantitatif yang merupakan penekanan pada pengujian teori melalui pengukuran variabel dengan angka dan melakukan analisis data dengan prosedur statistik. Variabel yang dianalisis terdiri dari tingkat profitability, solvability, ukuran perusahaan dan ukuran Kantor Auditor Publik. Variabel yang digunakan dalam tulisan ini terdiri dari dua kelompok utama yaitu variabel dependen dan variabel independen. Pengukuran masing-masing variabel yang digunakan dalam tulisan ini terdiri dari :

1. Variabel Dependen

Variabel dependen tulisan ini adalah Penundaan pemeriksaan. Variabel ini menggunakan skala interval. Alat analisis yang digunakan adalah analisis regresi berganda untuk mengukur Penundaan pemeriksaan. Variabel ini diukur berdasarkan banyaknya hari yang dibutuhkan untuk memperoleh laporan pemeriksaan independen atas pemeriksaan laporan keuangan periode tahunan perusahaan, sejak tanggal tutup buku perusahaan yaitu per 31 Desember sampai tanggal yang tertera pada laporan pemeriksaan independen.

2. Variabel Independen

a. Variabel Profitability diukur berdasarkan nilai ROA (Return on Asset) yaitu Net Profit dibagi dengan Total Asset. ROA dapat ditunjukkan dengan rumus sebagai berikut: ROA :

\section{$\underline{\text { Laba bersih }} x 100 \%$}

Total Aktiva

b. Variable Solvability

Merupakan perbandingan antara jumlah aktiva dengan jumlah hutang. Solvability mencerminkan kemampuan perusahaan untuk membayar seluruh kewajibannya, baik yang berupa hutang jangka pendek maupun jangka panjang apabila perusahaan tersebut dilikuidasi. Suatu perusahaan dikatakan solvable apabila perusahaan tersebut mempunyai aktiva atau kekayaan yang cukup untuk membayar semua hutangnya. Solvability dapat ditunjukkan oleh rumus sebagai berikut:

SOLV :

Total Hutang $x 100 \%$

Total Aktiva 
c. Variabel ukuran perusahaan

Diukur berdasarkan total assets/ total aktiva yang dimiliki oleh setiap perusahaan sampel dan digunakan sebagai tolok ukur skala perusahaan. Variabel ini diproksi dengan menggunakan logaritma.

d. Variabel ukuran Kantor Auditor Publik

Diukur dengan dummy yaitu Ukuran Kantor Auditor Publik Big Four diberi kode dummy 1, dan Non Big Four diberi kode dummy 0

\section{Sampel Tulisan}

Pengambilan sampel dalam tulisan ini menggunakan metode purposive sampling yaitu pemilihan sampel secara tidak acak yang informasinya diperoleh dengan menggunakan pertimbangan tertentu dimana umumnya disesuaikan dengan tujuan atau masalah tulisan.

Adapun kriteria-kriteria yang digunakan adalah sebagai berikut:

1. Perusahaan dalam sampel adalah perusahaan go public yang terdaftar di BEI untuk periode 2013-2016.

2. Perusahaan menerbitkan laporan keuangan per 31 Desember untuk periode 2013-2016 beserta laporan pemeriksaan yang memuat pendapat akuntan publik yang dipublikasikan.

3. Perusahaan masuk dalam kategori perusahaan manufaktur.

4. Memiliki data tanggal penyampaian laporan keuangan tahunan ke Bapepam ( OJK ) untuk periode 2013-2016.

\section{Rancangan Analisa Data}

Model analisis dalam pengujian yang dilakukan dalam tulisan ini adalah :
a. Statistik Deskriptif
b. Uji Asumsi Klasik
c. Uji Normalitas
1) Uji Multikoloneritas
2) Uji Autokorelasi
3) Uji Heteroskedastisitas

d. Pengujian Hipotesis

1) Uji Parsial

2) Uji Simultan

3) Koefisien Determinasi $\left(R^{2}\right) s$

\section{Hasil}

\section{Statistik Deskriptif}

Jumlah Populasi dan sampel ditunjukkan pada Tabel 2 Sampel yang digunakan dalam tulisan ini berjumlah 55 perusahaan untuk periode selama 4 tahun yaitu dari tahun 20132016.

Tabel 2

Populasi dan Sampel

\begin{tabular}{|l|l|l|}
\hline No. & Kriteria & Jumlah \\
\hline 1. & $\begin{array}{l}\text { Jumlah perusahaan manufaktur yang terdaftar di BEI pada } \\
\text { tahun 2013-2016 sebagai Populasi Tulisan }\end{array}$ & 156 \\
\hline 2. & $\begin{array}{l}\text { Perusahaan yang tidak melaporkan laporan keuangannya } \\
\text { berturut-turut secara tepat waktu selama periode tulisan. }\end{array}$ & Sampel \\
\hline & 55 \\
\hline & Data Pengamatan ( 4 x 55 ) & 220 \\
\hline & Sumber: Kriteria purposive sampling dalam tulisan ini, 2014 \\
\hline
\end{tabular}


eCo-Buss

Tabel 3

Statistik Deskriptif

\begin{tabular}{|l|r|r|r|r|r|}
\hline & $\mathrm{N}$ & Minimum & Maximum & Mean & Std. Deviation \\
\hline Profitablitas & 220 & -.756 & .416 & .08788 & .113663 \\
Solvabilitas & 220 & .037 & 1.049 & .47006 & .214004 \\
Ukuran Perusahaan & 220 & 11.634 & 30.057 & $2.33744 \mathrm{E} 1$ & 5.202358 \\
Penundaan pemeriksaan & 220 & 31 & 150 & 76.87 & 16.037 \\
Valid N (listwise) & 220 & & & & \\
\hline
\end{tabular}

Sumber : Output SPSS, 2014

Gambaran umum sampel dengan variabel profitabilitas, solvabilitas, ukuran perusahaan dan penundaan pemeriksaan dapat dilihat pada tabel 3. Berdasarkan hasil pengolahan data pada Tabel 3 diatas diketahui rata - rata profitabilitas dari 55 perusahaan yang hitung berdasarkan rumus ROA (Return on Asset) adalah sebesar 0,08. Nilai maksimum adalah sebesar 0,41 dan nilai minimum -0.75 . Nilai minimum pada hasil analisa yang negatif menunjukkan adanya perusahaan sampel yang mengalami kerugian. Standar deviasi $0,113>$ nilai rata-rata 0,08 menandakan perbedaan profit antar perusahaan adalah cukup besar.

Variabel solvabilitas yang dihitung berdasarkan rumus antara total hutang dengan total aktiva memiliki nilai rata-rata sebesar 0,47 dengan nilai maksimum adalah sebesar 1,04 dan nilai minimum 0,03. Standar deviasinya sebesar $0,214<$ nilai rata-rata 0,47 menandakan perbedaan kemampuan antara masing-masing perusahaan untuk memenuhi kewajibannya kecil.

Variabel ukuran perusahaan memiliki rata-rata sebesar 23,37. Rata-rata ukuran perusahaan dihitung berdasarkan logaritma total asset yang dimiliki oleh perusahaan dengan nilai minimum 11,63 dan nilai maksimum 30,05. Standar deviasi 52,02 > nilai rata-rata 23,3 menandakan nilai total asset antara masing-masing perusahaan berbeda jauh.

Tabel 4

Publikasi Laporan Keuangan Pemeriksaanan

\begin{tabular}{|l|r|r|r|r|}
\hline & & & & \multicolumn{2}{l|}{ Cumulative } \\
& Frequency & Percent & Valid Percent & Percent \\
\hline Valid & & & & \\
$30-60$ & 28 & 12.7 & 12.7 & 14.5 \\
$61-89$ & 180 & 81.8 & 81.8 & 96.4 \\
90 & 1 & .5 & .5 & 96.8 \\
$91-120$ & 7 & 3.2 & 3.2 & 100 \\
$121-150$ & 4 & 1.8 & 1.8 & 1.8 \\
Total & 220 & 100.0 & 100.0 & \\
\hline
\end{tabular}

Sumber : Output SPSS, 2014

Berdasarkan lampiran Keputusan Ketua Bapepam No. 40/BL/2007 yang menjelaskan mengenai kewajiban perusahaan publik untuk menyampaikan laporan keuangannnya, diatur mengenai penyampaian laporan keuangan perusahaan yang telah dipemeriksaan harus disampaikan selambat- lambatnya sembilan puluh hari atau tiga bulan yang dihitung sejak berakhirnya tahun buku. 
Berdasarkan tabel 4 dapat diketahui nilai rata-rata Penundaan pemeriksaan sebesar 77 hari dengan nilai maksimum Penundaan pemeriksaan sebesar 150 hari pada PT Suparma Tbk pada tahun 2011 dan nilai minimum 31 hari pada PT Holcim Indonesia Tbk pada tahun 2010. Standar deviasi sebesar 16,037 < nilai rata - rata 76,87 menandakan perbedaan lamanya Penundaan pemeriksaan antar perusahaan adalah kecil.

Dari Tabel 4.3 diketahui bahwa 96,4\% laporan keuangan disampaikan lebih awal dari batas waktu yang ditetapkan yaitu 90 hari setelah tanggal berakhirnya tutup buku. Hanya 0,5\% laporan keuangan disampaikan tepat 90 hari setelah tanggal berakhirnya tutup buku.

Variabel ukuran Kantor Auditor Publik menggunakan skala dummy, sehingga statistik deskriptifnya dilakukan secara terpisah. Ukuran Kantor Auditor Publik dilihat dari ada tidaknya afiliasi Kantor Auditor Publik yang digunakan oleh perusahaan sampel dengan Kantor Auditor Publik the big four.

Tabel 5

Hasil Analisis Statistik Deskriptif Variabel Dummy

Ukuran Kantor Akuntan Publik

\begin{tabular}{|ll|l|l|l|l|}
\hline & & & & \\
& & Frequency & Percent & Valid Percent & $\begin{array}{l}\text { Cumulative } \\
\text { Percent }\end{array}$ \\
\hline Valid & Non Big Four & 124 & 56.4 & 56.4 & 56.4 \\
& Big Four & 96 & 43.6 & 43.6 & 100.0 \\
& Total & 220 & 100.0 & 100.0 & \\
\hline
\end{tabular}

Sumber : Output SPSS, 2014

Berdasarkan data pada Tabel 5 dapat diketahui bahwa dari 220 data laporan keuangan 55 perusahaan sampel, sebanyak 56,4\% dipemeriksaan oleh Kantor Auditor Publik Non Big Four dan 43,6\% oleh Kantor Akuntan Publik Big Four. Sebanyak 24 perusahaan yang menggunakan jasa Kantor Auditor Publik yang berafiliasi dengan Kantor Auditor Publik Big Four, dan sebanyak 31 perusahaan menggunakan jasa Kantor Auditor Publik non Big Four.

\section{Uji Asumsi Klasik}

a. Uji Normalitas

Uji normalitas bertujuan untuk memperlihatkan bahwa data sampel berasal dari populasi yang berdistribusi normal. Pengujian normalitas yang digunakan dalam tulisan ini adalah metode deskriptif dengan parameter koefisien varian dimana data dikatakan berdistribusi normal jika nilai koefisien varians $<30 \%$.

Tabel 6

Koefisien Varian

\begin{tabular}{|l|l|l|l|l|l|}
\hline & N & Minimum & Maximum & Mean & Std. Deviation \\
\hline $\begin{array}{l}\text { Penundaan } \\
\text { pemeriksaan }\end{array}$ & 220 & 31 & 150 & 76.82 & 16.037 \\
Valid N (listwise) & 220 & & & & \\
\hline
\end{tabular}

Sumber : Output SPSS, 2014

Berdasarkan Tabel 6 maka dapat dihitung koefisien varian sebagai berikut : 


\section{eCo-Buss}

Rumus :

$\underline{\text { Standar Deviasi }} \times 100 \%$, maka $\underline{16,037 \times 100 \%}=21,21 \%$

Mean $\frac{16,037 \times 100 \%}{76,82}$

Sesuai dengan kriteria diatas, maka data dapat dikatakan berdistribusi normal, karena diperoleh koefisien varians $<30 \%$, yaitu sebesar $21,21 \%$.

\section{b. Uji Multikolonieritas}

Untuk mendeteksi ada tidaknya multikolinearitas dalam model regresi pada tulisan ini dilihat dari Tolerance Value atau Variance Inflation Factor (VIF).

1) Jika nilai Tolerance $>10$ persen dan nilai VIF $<10$, maka dapat disimpulkan bahwa tidak ada multikolinearitas antar variabel independen dalam model regresi.

2) Jika nilai Tolerance < 10 persen dan nilai VIF > 10, maka dapat disimpulkan bahwa ada multikolinearitas antar variabel independen dalam model regresi.

Tabel 7

Hasil Uji Multikolonieritas

\begin{tabular}{|cl|l|l|}
\hline \multirow{2}{*}{ Model } & \multicolumn{2}{|l|}{ Collinearity Statistics } \\
\cline { 3 - 4 } & & & \\
\hline 1 & (Colerance & VIF \\
\cline { 2 - 3 } & Profitabilitas & .717 & \\
& Solvabiltitas & .793 & 1.395 \\
& Ukuran Perusahaan & .704 & 1.261 \\
& Ukuran KAP & .663 & 1.420 \\
& &
\end{tabular}

c. Dependent Variable: Penundaan pemeriksaan

Sumber : Output SPSS, 2014

Berdasarkan hasil pengujian pada tabel 7 dapat diketahui bahwa nilai tolerance untuk variabel profitabilitas sebesar 0,717, Solvabilitas sebesar 0,793, Ukuran Perusahaan sebesar 0,704 dan Ukuran Kantor Akuntan Publik sebesar 0,663. Sedangkan untuk nilai VIF (Variance Inflation Factor) variabel profitabilitas sebesar 1,395, solvabilitas sebesar 1,261, ukuran perusahaan sebesar 1,420 dan ukuran Kantor Akuntan Publik sebesar 1,507. Dengan demikian dapat disimpulkan bahwa semua variabel independen mempunyai nilai tolerance $>0,10$ dan nilai $\mathrm{VIF}<10$. Hal ini menunjukkan bahwa dalam model regresi, tidak terjadi multikoleniaritas antar variabel independen.

\section{c. Uji Autokorelasi}

Untuk melakukan uji autokorelasi pada data tulisan ini menggunakan prosedur uji DurbinWatson (DW test) dengan menggunakan kriteria sebagai berikut :

1) Bila nilai DW berada di antara dU sampai dengan 4-dU maka koefisien autokorelasi sama dengan nol. Artinya, tidak ada autokorelasi.

2) Bila nilai DW lebih kecil daripada dL, koefisien autokorelasi lebih besar daripada nol. Artinya ada autokorelasi positif.

3) Bila nilai DW terletak di antara dL dan dU, maka tidak dapat disimpulkan.

4) Bila nilai DW lebih besar daripada 4-dL, koefisien autokorelasi lebih besar daripada nol. Artinya ada autokorelasi negatif.

5) Bila nilai DW terletak di antara 4-dU dan 4-dL, maka tidak dapat disimpulkan. 


\section{eCo-Buss}

Tabel 8

Hasil Uji Autokorelasi

\begin{tabular}{|r|r|r|r|r|r|}
\hline $\mathrm{M}$ & $\mathrm{R}$ & $\begin{array}{r}\mathrm{R} \\
\text { odel }\end{array}$ & $\begin{array}{c}\text { Square } \\
\text { Adjusted R } \\
\text { Square }\end{array}$ & $\begin{array}{r}\text { Std. Error of } \\
\text { the Estimate }\end{array}$ & $\begin{array}{c}\text { Durbin- } \\
\text { Watson }\end{array}$ \\
\hline 1 & $.289^{\mathrm{a}}$ & .083 & .064 & 16.036 & 2.159 \\
\hline
\end{tabular}

a. Predictors: (Constant), Ukuran KAP, Solvabiltitas, Profitabilitas, Ukuran Perusahaan

b. Dependent Variable: Penundaan pemeriksaan

Sumber : Output SPSS, 2014

Berdasarkan tabel diatas nilai Durbin-Watson yang dihasilkan dari model regresi di atas adalah 2,159. Dari tabel Durbin-Watson (lampiran 1) dengan signifikansi 5\%, dan jumlah data $(n)=220$, serta variabel independen $(\mathrm{k})=4$ diperoleh nilai dL sebesar 1,75161 dan nilai dU sebesar 1,80686 .

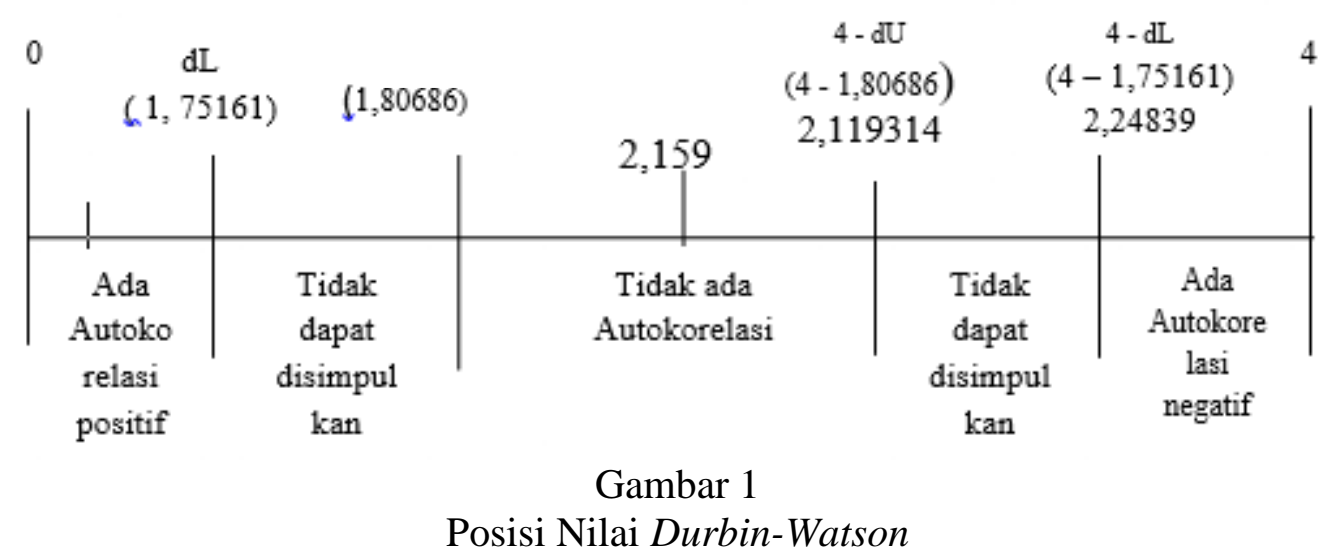

Gambar 1 dapat diketahui nilai Durbin-Watson sebesar 2,067 berada diantara dU sampai dengan 4 - dU maka koefisien autokorelasi sama dengan nol. Sehingga dapat disimpulkan bahwa model regresi ini tidak ada autokorelasi.

\section{d. Uji Heteroskedastisitas}

Untuk melakukan uji heteroskedastisitas pada data tulisan ini menggunakan prosedur uji Glejser. Tingkat signifikansi yang diterapkan dalam tulisan ini adalah 5\%.

Dengan prosedur uji Glejser, hasil uji heteroskedastisitas menggunakan kriteria :

1) Apabila nilai signifikansi lebih besar dari 0,05 maka tidak terjadi gejala Heteroskedastisitas

2) Apabila nilai signifikansi lebih kecil dari 0,05 maka terjadi gejala Heteroskedastisitas. 
eCo-Buss

Tabel 9

Hasil Uji Heteroskedatisitas Metode Glejser

Coefficients $^{\mathrm{a}}$

\begin{tabular}{|c|c|c|c|c|c|c|}
\hline \multirow{2}{*}{\multicolumn{2}{|c|}{ Model }} & \multicolumn{2}{|c|}{$\begin{array}{l}\text { Unstandardized } \\
\text { Coefficients }\end{array}$} & \multirow{2}{*}{\begin{tabular}{|l} 
Standardized \\
Coefficients \\
Beta
\end{tabular}} & \multirow[b]{2}{*}{$\mathrm{t}$} & \multirow[b]{2}{*}{ Sig. } \\
\hline & & $B$ & Std. Error & & & \\
\hline \multirow[t]{5}{*}{1} & (Constant) & 13.712 & 5.224 & & 2.625 & .009 \\
\hline & Profitabilitas & -16.408 & 7.555 & -.173 & 2.172 & .105 \\
\hline & Solvabiltitas & -2.939 & 3.796 & -.058 & -.774 & .440 \\
\hline & Ukuran Perusahaan & -.040 & .167 & -.019 & -.241 & .810 \\
\hline & Ukuran KAP & 2.219 & 1.804 & .102 & 1.230 & .220 \\
\hline
\end{tabular}

a. Dependent Variable: abresid

Sumber : Output SPSS, 2014

Pada Tabel 9 diketahui bahwa nilai signifikansi (sig) variabel profitabilitas sebesar 0,105, solvabilitas sebesar 0,440, ukuran perusahaan sebesar 0,810 dan ukuran KAP sebesar 0,220 . Hal ini menunjukkan bahwa semua variabel independen memiliki nilai signifikansi lebih besar dari 0,05 sehingga dapat disimpulkan bahwa tidak ada gejala heteroskedastisitas pada model regresi tulisan ini.

\section{Uji Hipotesis}

Model regresi berganda dalam tulisan ini adalah sebagai berikut :

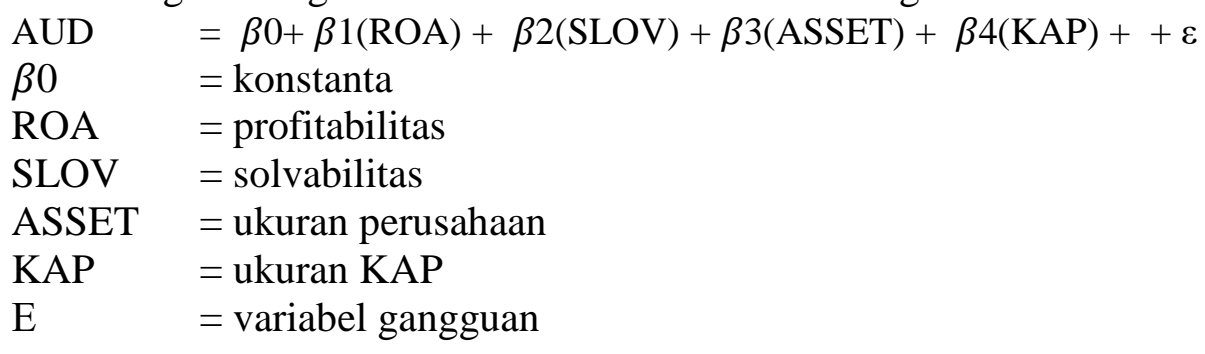

\section{a. Uji Signifikansi Parsial ( Uji t)}

Uji t adalah pengujian koefisien regresi masing-masing variabel independen terhadap variabel dependen untuk mengetahui seberapa besar pengaruh variabel independen terhadap variabel dependen. 
eCo-Buss

Tabel 10

Hasil Uji t

\begin{tabular}{|c|c|c|c|c|c|c|}
\hline \multirow{2}{*}{\multicolumn{2}{|c|}{ Model }} & \multicolumn{2}{|c|}{$\begin{array}{l}\text { Unstandardized } \\
\text { Coefficients }\end{array}$} & \multirow{2}{*}{\begin{tabular}{|l} 
Standardized \\
Coefficients \\
Beta \\
\end{tabular}} & & \multirow[b]{2}{*}{ Sig. } \\
\hline & & B & Std. Error & & & \\
\hline & (Constant) & 58.964 & 8.357 & & 7.056 & .000 \\
\hline & Profitabilitas & 5.898 & 11.947 & .040 & .494 & .622 \\
\hline & Solvabiltitas & 16.179 & 5.961 & .211 & 2.714 & .007 \\
\hline & Ukuran Perusahaan & .473 & .267 & .146 & 1.769 & .078 \\
\hline & Ukuran KAP & -3.057 & 2.841 & -.091 & 1.076 & .283 \\
\hline
\end{tabular}

a. Dependent Variable: Penundaan

pemeriksaan

Sumber : Output SPSS ( 2014)

Uji Hipotesis 1:

H1: Tingkat Profitabilitas berpengaruh secara signifikan terhadap Penundaan pemeriksaan.

Pada Tabel 10 di atas, dapat diketahui nilai signifikansi variabel profitabilitas sebesar 0,622. Nilai ini lebih besar dari 0,05, hal ini dapat di tarik kesimpul bahwa tingkat profitabilitas tidak berpengaruh secara signifikan terhadap Penundaan pemeriksaan. Profitabilitas menunjukkan keberhasilan perusahaan dalam menghasilkan keuntungan, sehingga dapat dikatakan merupakan berita baik bagi perusahaan untuk dapat secepat mungkin diumumkan kepada publik dalam hal ini para penanam modal dan pihak-pihak yang berkepentingan. Kemampuan perusahaan untuk menghasilkan laba berdasarkan aktiva yang dimiliki ternyata tidak mempunyai pengaruh secara signifikan terhadap Penundaan pemeriksaan.

Tulisan ini sesuai dengan hasil tulisan Hosain dan Taylor (1998) yang memberikan kesimpulan dimana tidak ada hubungan yang signifikan antara tingkat profitabilitas dengan Penundaan pemeriksaan. Hasil tulisan Yuliyanti (2011) juga memberikan kesimpulan profitabilitas tidak mempunyai pengaruh signifikan terhadap Penundaan pemeriksaan.

Uji Hipotesis 2:

H2: Solvabilitas berpengaruh secara signifikan terhadap Penundaan pemeriksaan.

Pada Tabel 4.8 dapat diketahui nilai signifikansi variabel solvabilitas sebesar 0,007. Nilai ini lebih kecil dari 0,05 , hal ini dapat disimpulkan bahwa solvabilitas berpengaruh secara signifikan terhadap Penundaan pemeriksaan.

Solvabilitas menunjukkan kemampuan perusahaan untuk memenuhi segala kewajiban finansialnya pada saat dilikuidasi. Proporsi yang besar dari hutang terhadap total aktiva akan meningkatkan kecenderungan kerugian dan dapat meningkatkan kehati-hatian pemeriksaan terhadap laporan keuangan yang akan dipemeriksaan.

Hasil tulisan ini menunjukkan bahwa solvabilitas berpengaruh secara signifikan terhadap Penundaan pemeriksaan, berarti bahwa kemampuan perusahaan untuk memenuhi kewajiban finansialnya mempunyai pengaruh yang signifikan terhadap lamanya proses penyampaian laporan pemeriksaanan atas laporan keuangan.

Tulisan ini sesuai dengan hasil tulisan Hersugondo (2013) dan Febrianty (2011) yang memberikan kesimpulan bahwa ada pengaruh signifikan solvabilitas terhadap Penundaan pemeriksaan. Rasio solvabilitas yang tinggi mengakibatkan panjangnya waktu yang 
dibutuhkan dalam penyelesaian pemeriksaan. Kemungkinan lain yaitu kurang ketatnya aturan-aturan dalam perjanjian utang di Indonesia untuk mengharuskan penyajian laporan keuangan pemeriksaanan perusahaan secara tepat waktu.

Uji Hipotesis 3 :

H3: Ukuran Perusahaan berpengaruh secara signifikan terhadap Penundaan pemeriksaan. Pada tabel 4.8 menunjukkan nilai signifikansi variabel ukuran perusahaan sebesar 0,078, nilai ini lebih besar dari 0,05 . Hal ini berarti bahwa ukuran perusahaan yang dihitung berdasarkan total aktivanya tidak berpengaruh secara signifikan terhadap Penundaan pemeriksaan.

Menurut Warren et.al (2008:52) perusahaan besar diduga akan menyelesaikan proses pemeriksaannya lebih cepat dibandingkan dengan perusahaan kecil. Hal ini disebabkan oleh adanya internal control yang baik dan kemampuan perusahaan untuk mendorong pemeriksaannya agar menyelesaikan pekerjaan pemeriksaan secara tepat waktu. Namun hasil tulisan ini menunjukkan bahwa ukuran perusahaan tidak berpengaruh terhadap Penundaan pemeriksaan. Semua perusahaan diawasi oleh para penanam modal, regulator dan berbagai pihak lain, sehingga setiap perusahaan dituntut untuk dapat menyelesaikan laporan keuangan pemeriksaanannya secara tepat waktu.

Hasil tulisan ini menunjukkan bahwa ukuran perusahaan tidak berpengaruh secara signifikan terhadap Penundaan pemeriksaan. Ukuran perusahaan, tidak berpengaruh signifikan terhadap Penundaan pemeriksaan karena proses pemeriksaan dapat lebih cepat kemungkinan dikarenakan jumlah tim yang ikut dalam pemeriksaan, bila jumlah timnya banyak maka pemeriksaan dapat dilaksanakan lebih cepat meskipun memeriksa perusahaan dengan persediaan fisik banyak.

Tulisan ini sesuai dengan hasil tulisan Agustina dan Aldie (2013) yang menyatakan bahwa secara parsial ukuran perusahaan tidak berpengaruh terhadap Penundaan pemeriksaan. Hal ini membuktikan bahwa teori yang menyatakan suatu perusahaan besar akan lebih pendek Penundaan pemeriksaannya tidak sepenuhnya benar. Tidak berpengaruhnya total asset terhadap ketepatan terbitnya laporan pemeriksaan disebabkan baik perusahaan yang besar maupun kecil memiliki kemungkinan telah melakukan pengendalian internal yang memadai sehingga walaupun total assetnya kecil namun pengendalian internalnya memadai maka penyampaian laporan keuangan pemeriksaanan telah ditentukan waktunya.

Uji Hipotesis 4 :

H4: Ukuran Kantor Akuntan Publik berpengaruh secara signifikan terhadap penundaan pemeriksaan.

Pada tabel 4.8 menunjukkan nilai signifikansi variabel ukuran Kantor Auditor Publik sebesar 0,283. Nilai ini lebih besar dari 0,05. Hal ini berarti bahwa ukuran Kantor Auditor Publik yang dikategorikan dengan Kantor Auditor Publik Big Four dengan Kantor Auditor Publik non Big Four tidak berpengaruh secara signifikan terhadap Penundaan pemeriksaan. Panjang pendeknya waktu yang dibutuhkan untuk menyelesaikan laporan pemeriksaanan bukan dilihat dari besar kecilnya Kantor Akuntan Pblik namun dapat ditentukan dari besar kecilnya tim yang melakukan pemeriksaan. Pekerjaan pemeriksaan akan lebih cepat bila jumlah tim yang ditugaskan banyak dibandingkan dengan tim dengan jumlah sedikit.

Tulisan ini sesuai dengan hasil tulisan Prabandari dan Rustiana (2007) serta Agustina dan Aldie (2013) yang menyatakan bahwa ukuran Kantor Auditor Publik tidak berpengaruh terhadap penundaan pemeriksaan. 
Dengan demikian dapat disimpulkan bahwa hanya variabel solvabilitas yang memiliki pengaruh signifikan terhadap Penundaan pemeriksaan. Sedangkan variabel independen lainnya (profitabilitas, ukuran perusahaan dan ukuran Kantor Auditor Publik) tidak memiliki pengaruh signifikan terhadap penundaan pemeriksaan karena memiliki nilai signifikansi $>0,05$.

Dari tabel di atas, maka persamaan regresi pada tulisan ini dapat dirumuskan menjadi:

$\mathrm{AUD}=58,964+5,898(\mathrm{ROA})+16,176(\mathrm{SLOV})+0,473(\mathrm{ASSET})-3,057(\mathrm{KAP})+\varepsilon$

Dari persamaan regresi diatas dapat dijelaskan sebagai berikut :

1) Konstanta sebesar 58,964 menunjukkan bahwa jika tidak ada variabel independen (X1,X2,X3 dan X4) maka Penundaan pemeriksaan perusahaan manufaktur yng terdaftar di BEI tahun 2010 - 2013 sebesar 58,964 hari.

2) $\beta 1$ sebesar 5,898 dan XI adalah ROA, menunjukkan bahwa setiap kenaikan ROA ( profitabilitas ) sebesar 1 satuan akan menaikkan Penundaan pemeriksaan sebesar 5,898. Dengan asumsi variabel lain tetap. Hal ini juga berarti kenaikan profitabilitas perusahaan berpengaruh positif terhadap Penundaan pemeriksaan.

3) $\beta 2$ sebesar 16,176 dan $X 2$ adalah solvabilitas, menunjukkan bahwa setiap kenaikan SLOV (solvabilitas) sebesar 1 satuan maka akan menaikkan Penundaan pemeriksaan sebesar 16,176. Dengan asumsi variabel lain tetap. Hal ini juga berarti kenaikan solvabilitas perusahaan berpengaruh positif terhadap Penundaan pemeriksaan.

4) $\beta 3$ sebesar 0,473 dan $X 3$ adalah ukuran perusahaan, menunjukkan bahwa setiap kenaikan ASSET (Ukuran perusahaan) sebesar 1 satuan maka akan menaikkan Penundaan pemeriksaan sebesar 0,473. Dengan asumsi variabel lain tetap. Hal ini juga berarti kenaikan ukuran perusahaan berpengaruh positif terhadap Penundaan pemeriksaan.

5) $\beta 4$ sebesar - 3,057 dan X4 adalah ukuran KAP.

\section{b. Uji Simultan ( Uji F )}

Uji F merupakan pengujian hubungan regresi secara simultan dari variabel-variabel dependen yang bertujuan apakah secara bersama-sama seluruh variabel independen mempunyai pengaruh yang signifikan terhadap variabel dependen. Kriteria penerimaan atau penolakan hipotesis adalah:

1) Jika $f$ hitung $>\mathrm{f}$ tabel maka Ho ditolak

Jika f Hitung $<\mathrm{f}$ tabel maka Ho diterima

2) Berdasarkan signifikansi, dasar pengambilan keputusannya adalah:

Jika signifikansi $<0,05$ maka Ho ditolak

Jika signifikansi > 0,05 maka Ho diterima 
eCo-Buss

Tabel 11

Hasil Uji F

ANOVA $^{\mathrm{b}}$

\begin{tabular}{|cl|r|r|r|r|r|}
\hline Model & & Sum of Squares & df & Mean Square & F & Sig. \\
\hline 1 & Regression & 4495.327 & 4 & 1123.832 & 4.370 & $.002^{\mathrm{a}}$ \\
& Residual & 49372.988 & 192 & 257.151 & & \\
& Total & 53868.315 & 196 & & & \\
\hline
\end{tabular}

a. Predictors: (Constant), Ukuran KAP, Solvabiltitas, Profitabilitas, Ukuran perusahaan

b. Dependent Variable: Penundaan pemeriksaan

Uji Hipotesis 5:

H5: Tingkat profitability, solvability, ukuran perusahaan dan ukuran Kantor Akuntan Publik tidak berpengaruh secara simultan terhadap penundaan pemeriksaan.

Pada Tabel 11 di atas, dapat diketahui nilai $F$ hitung sebesar 4,370 dan dari tabel statistik F tabel 12 pada tingkat signifikansi 0,05 dengan df1 $(5-1)=4$ dan df2 $(220-4-1)=215$, diperoleh nilai $\mathrm{F}$ tabel sebesar 2,41.

Maka, dengan $\mathrm{F}$ hitung lebih besar dari $\mathrm{F}$ tabel $(4,370>2,41)$ dapat disimpulkan bahwa variabel independen secara simultan berpengaruh terhadap variabel dependen, maka H5 ditolak.

Dari tabel di atas juga diperoleh nilai signifikansi sebesar 0,002. Karena nilai 0,002 lebih kecil dari 0,05 maka variabel independen secara simultan memiliki pengaruh yang signifikan dengan variabel dependen.

\section{c. Hasil Uji Koefisien Determinasi $\left(\mathbf{R}^{2}\right)$}

Tabel 12

\section{Hasil Koefisien Determinasi $\left(\mathbf{R}^{2}\right)$}

Model Summary

\begin{tabular}{|c|r|r|r|l|}
\hline & & & & \multicolumn{2}{|l|}{$\begin{array}{l}\text { Std. Error of the } \\
\text { Estimate }\end{array}$} \\
\hline 1 & & R Square & Adjusted R Square & 16.036 \\
\hline
\end{tabular}

a. Predictors: (Constant), Ukuran KAP, Solvabiltitas, Profitabilitas, Ukuran

Perusahaan

Pada Tabel 12 di atas, diperoleh nilai $\mathrm{R}$ square sebesar 0,083 tingkat korelasi antara variabel independen dengan variabel dependennya sebesar 8,3\%. Hal ini berarti bahwa variabel profitability, solvability, ukuran perusahaan dan ukuran Kantor Akuntan Publik memiliki hubungan yang lemah dengan variabel penundaan pemeriksaan karena memiliki nilai dibawah 50\%. Nilai $\mathrm{R}$ square sebesar 0,083 yang berarti bahwa variasi variabel independen yang digunakan dalam model (ROA, SOLV, ASSET dan Kantor Akuntan Publik) dapat menjelaskan sebesar 8,3\% variasi variabel dependen (penundaan pemeriksaan). Sedangkan sisanya sebesar $91,7 \%$ dipengaruhi oleh variabel lain yang tidak diujikan dalam model ini. 


\section{Pengaruh Variabel Independen Terhadap Penundaan pemeriksaan}

a. Pengaruh Tingkat Profitabilitas Terhadap Penundaan pemeriksaan

Hasil pengujian statistik t menunjukkan bahwa variabel profitabilitas (X1) memiliki nilai koefisien sebesar 5,898. Hal ini menunjukkan bahwa tingkat profitabilitas memiliki pengaruh positif terhadap penundaan pemeriksaan yaitu semakin besar tingkat pendapatan/laba yang diperoleh perusahaan maka semakin lama proses pemeriksaan dilakukan.

Pada hasil uji t juga diketahui bahwa tingkat signifikansi variabel profitabilitas sebesar 0,622. Hasil yang diperoleh tersebut menyatakan bahwa profitabilitas tidak berpengaruh secara signifikan terhadap Penundaan pemeriksaan. Nilai signifikansinya lebih besar dari tingkat signifikansi sebesar 0,05 . Walaupun semakin besar tingkat pendapatan/laba perusahaan berpengaruh terhadap penundaan pemeriksaan, tetapi pengaruhnya tidak signifikan.

H1: Tingkat Profitabilitas berpengaruh secara signifikan terhadap Penundaan pemeriksaan.

Berdasarkan hasil yang diperoleh maka dapat disimpulkan hipotesis pertama ditolak.

\section{b. Pengaruh Tingkat Solvabilitas Terhadap Penundaan pemeriksaan}

Berdasarkan hasil pengujian pada tabel 12 hasil uji t, diketahui bahwa nilai koefisien variabel solvabilitas (X2) sebesar 16,179. Hal ini menunjukkan bahwa tingkat solvabilitas memiliki pengaruh positif terhadap Penundaan pemeriksaan. Sedangkan nilai signifikansi variabel solvabilitas sebesar 0,007 yang berarti<dari 0,05 . Hal ini menunjukkan bahwa solvabilitas berpengaruh secara signifikan terhadap Penundaan pemeriksaan.

Besarnya jumlah hutang yang dimiliki perusahaan akan menyebabkan proses pemeriksaan semakin lama. Proporsi hutang terhadap aktiva yang relatif tinggi juga mungkin akan membuat pemeriksaan perlu meningkatkan kehati-hatian dan ketelitian yang lebih dalam pemeriksaan terkait dengan kelangsungan hidup perusahaan (going concern).

H2: Solvabilitas berpengaruh secara signifikan terhadap Penundaan pemeriksaan.

Berdasarkan hasil yang diperoleh maka dapat disimpulkan hipotesis kedua diterima.

\section{c. Pengaruh Ukuran Perusahaan Terhadap Penundaan pemeriksaan}

Berdasarkan hasil pengujian pada tabel 12 hasil uji t, diketahui bahwa nilai koefisien variabel ukuran perusahaan (X3) sebesar 0,473. Hal ini menunjukkan bahwa ukuran perusahaan memiliki pengaruh positif terhadap Penundaan pemeriksaan. Sedangkan nilai signifikansi variabel ukuran perusahaan sebesar 0,078 yang berarti>dari 0,05 . Hal ini menunjukkan bahwa ukuran perusahaan tidak berpengaruh secara signifikan terhadap Penundaan pemeriksaan.

Semakin besar total asset yang dimiliki oleh suatu perusahaan maka semakin besar Penundaan pemeriksaan-nya, namun pengaruhnya tidak signifikan.

H3: Ukuran Perusahaan berpengaruh secara signifikan terhadap Penundaan pemeriksaan.

Berdasarkan hasil yang diperoleh maka dapat disimpulkan hipotesis ketiga ditolak.

\section{d. Pengaruh Ukuran Kantor Akuntan Publik Trhadap Penundaan pemeriksaan}

Hasil pengujian statistik t menunjukkan bahwa variabel ukuran Kantor Auditor Publik (X4) memiliki nilai koefisien sebesar -3,057. Hal ini menunjukkan bahwa ukuran Kantor Auditor Publik memiliki pengaruh negatif terhadap Penundaan pemeriksaan yaitu bahwa tidak terdapat pengaruh terhadap Penundaan pemeriksaan bagi perusahaan yang dipemeriksaan oleh Kantor Akuntan Publik yang besar, baik itu Kantor Akuntan Publik Big maupun Kantor Auditor Publik Non-Big. 
Sedangkan nilai signifikansi variabel ukuran perusahaan sebesar 0,283 yang berarti>dari 0,05. Hal ini menunjukkan bahwa ukuran perusahaan tidak berpengaruh secara signifikan terhadap Penundaan pemeriksaan.

H4: Ukuran Kantor Auditor Publik berpengaruh secara signifikan terhadap Penundaan pemeriksaan.

Berdasarkan hasil yang diperoleh maka dapat disimpulkan hipotesis ketiga ditolak.

\section{Simpulan}

Tulisan ini meneliti pengaruh tingkat profitabilitas, solvabilitas, ukuran perusahaan dan ukuran Kantor Auditor Publik terhadap Penundaan pemeriksaan pada perusahaan manufaktur yang terdaftar di Bursa Efek Indonesia tahun 2013-2016 dengan jumlah sampel 55 perusahaan.

Berdasarkan hasil analisis diperoleh kesimpulan, antara lain:

1. Tingkat profitabilitas tidak berpengaruh secara signifikan terhadap Penundaan pemeriksaan. Hal tersebut karena nilai signifikansi variabel profitabilitas sebesar 0,622>0,05. Hasil Tulisan ini sesuai dengan hasil tulisan Hosain dan Taylor (1998) serta Yuliyanti (2011).

2. Solvabilitas berpengaruh secara signifikan terhadap Penundaan pemeriksaan. Hal tersebut karena nilai signifikansi variabel solvabilitas sebesar $0,007<0,05$. Hasil Tulisan ini sesuai dengan hasil tulisan Hersugondo (2013) dan Febrianty (2011).

3. Ukuran Perusahaan tidak berpengaruh secara signifikan terhadap Penundaan pemeriksaan. Hal tersebut karena nilai signifikansi variabel ukuran perusahaan sebesar 0,078>0,05. Hasil tulisan ini sesuai dengan tulisan Agustina dan Aldie (2013).

4. Ukuran Kantor Auditor Publik tidak berpengaruh secara signifikan terhadap Penundaan pemeriksaan. Hal tersebut karena nilai signifikansi variabel ukuran Kantor Auditor Publik sebesar 0,283>0,05. Hasil tulisan ini sesuai dengan hasil tulisan Prabandari dan Rustiana (2007) serta Agustina dan Aldie (2013).

5. Tingkat profitabilitas, solvabilitas, ukuran perusahaan dan ukuran Kantor Auditor Publik berpengaruh secara simultan terhadap Penundaan pemeriksaan.

Berdasarkan hasil tulisan juga diketahui bahwa rata-rata Penundaan pemeriksaan perusahaan sampel adalah 77 hari. Perusahaan yang terlambat melaporkan laporan keuangan pemeriksaanannya kepada OJK hanya sebesar 3,2\% dari keseluruhan sampel perusahaan. Hal ini merupakan dampak dari peraturan yang dikeluarkan oleh OJK mengenai aturan penyampaian laporan keuangan dan sanksi.

\section{Daftar Pustaka}

Ahmed, A. A., \& Hossain , M. S. (2010). Keterlambatan pemeriksaan laporan: A Study of the Bangladeshi Listed Companies. ASA University Review, 49-56.

Angruningrum, S., \& Wirakusuma, M. G. (2013). Pengaruh Profitabilitas, Leverage, Kompleksitas Operasi, Reputasi KAP dan Komite Pemeriksaan pada Penundaan pemeriksaan. E-Jurnal Akuntansi Universitas Udayana, 251-270.

Asthon, R. H., Willingham, J. J., \& Elliot, R. K. (1987). An Empirical Analysis of Penundaan pemeriksaan. Journal of Accounting Research, 275-292.

beritasatu. (2014, 4 15). Penanam modal Daily - 49 Emiten Belum Serahkan Laporan Keuangan 2013. Diambil kembali dari www.beritasatu.com: www.beritasatu.com

Carslaw, C., \& Kaplan, S. (1991). An Examination of Pemeriksaan. Accounting and Bussiness Research, 45-46.

Efendi, D., \& Utami, I. T. (2012). Faktor-faktor yang Mempengaruhi Penundaan pemeriksaan (Studi Empiris Perusahaan Manufaktur yang List di BEI). Ekonomika, 64-68. 
Febrianty. (2011). Faktor-Faktor Yang Berpengaruh Terhadap Penundaan pemeriksaan Perusahaan Sektor Perdagangan Yang Terdaftar di BEI Periode 2007-2009. Jurnal Ekonomi dan Informasi Akuntansi (Jenius), 294-320.

Halim, V. (2000). Faktor-faktor Yang Memperngaruhi Penundaan pemeriksaan. Jurnal Bisnis Akuntansi, 63-75.

Handayani, A. P., \& Wirakusuma, M. G. (2013). Pengaruh Profitabilitas, Solvabilitas, Reputasi Kantor Akuntan Publik pada Ketidaktepatwaktuan Publikasi Laporan Keuangan Perusahaan di BEI. E-Jurnal Akuntansi, 472-488.

Harahap , S. S. (2007). Teori Akuntansi. Jakarta: PT. Rajagrafindo Persada.

Hersugondo, \& Kartika, A. (2013). Prediksi Probabilitas Penundaan pemeriksaan dan Faktor Determinannya. Proceeding Fakultas Ekonomi Unisbank. UNISBANK.

Hugh, A. M., \& Dyers , J. (1975). The Timeliness of the Australian. Journal of Accounting Research, 204-219.

Indriyani, R. E., \& Supriyati. (2012). Faktor-faktor yang Mempengaruhi Keterlambatan pemeriksaan laporan Perusahaan Manufaktur di Indonesia dan Malaysia. The Indonesian Accounting Review, 185 - 202.

Kartika, A. (2009). Faktor-faktor yang Mempengaruhi Penundaan pemeriksaan di Indonesia (Studi Empiris pada Perusahaan-perusahaan LQ 45 yang Terdaftar di Bursa Efek Jakarta. Jurnal Bisnis dan Ekonomi (JBE), 1-17.

Lawrence, J., \& Glover, H. (1998). The Effect of Pemeriksaan Firm Mergers on Penundaan pemeriksaan. Journal of Managerial, 151-165.

Lianto, N., \& Kusuma, B. H. (2010). Faktor-faktor yang Mempengaruhi Terhadap Keterlambatan pemeriksaan laporan. Jurnal Bisnis dan Akuntansi, 97-106.

Yanti, L. D., \& Oktari, Y. (2018). Konversi Faktor Penerimaan Audit Teknologi oleh Kantor Akuntan Publik di Indonesia Menggunakan Kerangka Kerja I-TOE. eCo-Buss, 1(1), 1-6.

Subekti, I., \& Widiyanti, N. W. (2004). Faktor-faktor Yang Berpengaruh Terhadap Penundaan pemeriksaan di Indonesia. SNA VII Denpasar Bali, (hal. 991-1002). Denpasar. 